\title{
Historical presence (1975-1985) of mycobacteriosis in Chesapeake Bay striped bass Morone saxatilis
}

\author{
John M. Jacobs ${ }^{1, *}$, Dorothy W. Howard ${ }^{1}$, Matt R. Rhodes ${ }^{1}$, Martin W. Newman' ${ }^{1}$, \\ Eric B. May ${ }^{2}$, Reginal M. Harrell ${ }^{3}$ \\ ${ }^{1}$ NOAA/NOS/CCEHBR/Cooperative Oxford Lab, Oxford, Maryland 21654, USA \\ ${ }^{2}$ University of Maryland, Eastern Shore, Princess Anne, Maryland 21853, USA \\ ${ }^{3}$ University of Maryland, Department of Environmental Sciences and Technology, College Park, Maryland 20742, USA
}

\begin{abstract}
A retrospective analysis of archived tissue blocks has revealed that mycobacteriosis was apparent in Chesapeake Bay striped bass as early as 1984. Of 37 cases available from the years 1975 to 1985, 2 fish were found positive based on histopathology and genus-specific PCR. Multi-gene sequencing places the bacteria from the 2 positive cases (1984 and 1985) within the Mycobacterium tuberculosis clade with closest resemblance to the recently described fish pathogen M. pseudoshottsii. Our data confirms that mycobacteriosis is not a new disease of Chesapeake Bay striped bass and underscores the value of archived tissues in epidemiological examinations.
\end{abstract}

KEY WORDS: Mycobacteriosis · Striped bass · PCR · Paraffin-embedded tissues Resale or republication not permitted without written consent of the publisher

\section{INTRODUCTION}

Mycobacteriosis is a chronic progressive bacterial disease of fish caused by several species of the genus Mycobacterium. The disease is common and problematic in both aquaculture (Stoskopf 1993, Colorni et al. 1998) and in wild marine fisheries (Jacobs et al. 2009). In 1997, mycobacteria were cultured from Chesapeake Bay striped bass Morone saxatilis exhibiting external ulcerative lesions and internal granulomatous inflammation (Heckert et al. 2001, Rhodes et al. 2001). Over the past $10 \mathrm{yr}$, several research efforts have demonstrated that disease prevalence increases with age and a high proportion $(>50 \%)$ of mature fish are affected (Overton et al. 2003, Rhodes et al. 2004, Kaattari et al. 2005, Ottinger \& Jacobs 2006). Further complicating the matter is that there appears to be not one Mycobacterium sp. involved, but several, including 2 novel members of the genus, $M$. shottsii (Rhodes et al. 2003) and M. pseudoshottsii (Rhodes et al. 2005). Other species phenotypically resembling $M$. marinum, $M$. interjectum, M. scrofulaceum, M. szulgai and M. triplex have also been isolated (Rhodes et al. 2004). While $M$. marinum can cause severe and often fatal infections in fish (Colorni et al. 1998, Wolf \& Smith 1999), it is rarely cultured from affected striped bass in Chesapeake Bay (Rhodes et al. 2004). M. shottsii is the primary isolate (Rhodes et al. 2004).

Only with the recent threat posed by mycobacteriosis in Chesapeake Bay have health surveys with statistically valid designs been routinely conducted for striped bass. Thus, the timing of the actual onset of the disease in Chesapeake Bay striped bass is unknown. In this paper, we describe an effort to review historical archived tissues with the specific intent to determine if mycobacteriosis was present in Chesapeake Bay striped bass. Further, we describe the application of molecular tools to candidate tissues which offer a level of sensitivity and discrimination not possible in earlier investigations (Crumlish et al. 2007).

\section{MATERIALS AND METHODS}

Tissue samples. Paraffin-embedded tissue samples of age 1+ wild-captured striped bass were selected from the Oxford Laboratory archives dating from 1975 to 1985 . The majority of available tissues from 1975 to 
1985 were from 'service samples,' or those brought to the Oxford Laboratory by other researchers or concerned anglers and watermen for expert opinion on disease status. Tissues were predominantly preserved in formalin-based fixatives during this time period. A total of 37 cases of wild-collected striped bass were included in this retrospective study.

Histopathology. Replicate $5 \mu \mathrm{m}$ sections were taken from archived tissue blocks and stained with hemotoxylin and eosin (H\&E) for initial screening. All available sections were examined with light microscopy for the presence of granulomas, inflammatory foci, or necrotic lesions associated with mycobacterial infections. Only obvious parasitic granulomas were excluded from the initial screening. All tissues containing the above pathologies were stained with ZiehlNeelsen for visualization of acid-fast bacilli (AFB) performed at $600 \times$ magnification. Samples containing clearly visible acid-fast, non-branching rods were considered histopathology positive (AFB+). Otherwise, samples were categorized as negative.

Molecular detection and identification. DNA from positive cases was extracted from paraffin-embedded tissues. Briefly, microtomes were sterilized with $70 \%$ ethanol (EtOH) and new, sterile blades were used for sectioning each block. After removal of several sections from the block's surface, 3 serial $5 \mu \mathrm{m}$ sections were cut, specific tissue sections segregated when possible, captured on a sterile wooden applicator, and transferred directly to sterile $1.5 \mathrm{ml}$ micro-centrifuge tubes. Sections were deparaffinized with xylene and DNA extracted with Qiagen's DNeasy kit according to manufacturer's instructions for paraffin-embedded tissues with modification. Three ethanol (100\%) rinses were performed after the use of xylene for paraffin removal, followed by complete evaporation in a vacuum centrifuge for $15 \mathrm{~min}$. Elution from spin filters was performed twice to a total volume of $70 \mu \mathrm{l}$. Paraffinembedded splenic tissue from a single fish challenged with Mycobacterium marinum was used as an extraction control.

Samples were screened for the presence of mycobacteria using a real-time PCR assay targeting a genus-specific region of the ribosomal 16-23S intergenic transcribed spacer (ITS) region (Bruijnesteijn van Coppenraet et al. 2004). The ITS is variable enough to distinguish fast- and slow-growing mycobacteria; however, it is homologous among several of the primary mycobacteria commonly encountered in Chesapeake Bay striped bass. Therefore, multiple primer sets targeting several genes were necessary for subsequent sequencing (Kaattari et al. 2006). Sequence analysis of the exported repeated protein (erp) gene and presence of the insertional sequences IS2404 and IS2606 were used to further distinguish members of the tuberculosis clade using published primer sets (Stinear et al. 1999, Mendonca-Lima et al. 2001, Rhodes et al. 2005, Kaattari et al. 2006). In one case, a nested PCR was performed to amplify the erp gene due to low template concentration (sample 85-4). A new primer set was designed to amplify product created by the assay of Rhodes et al. (2005) (F: 5'-TGT CCT CGT TCG GGA TCA ATC TG-3', R: 5' -TCA ACG CCG GAT TGG TGA GT-3'). Positive samples were either gel extracted and purified using a Qiagen QIAquick Gel extraction kit or directly purified from PCR product using Agencourt's AMPure kit (Agencourt Bioscience). Sequencing was performed at the University of Maryland, Center of Marine Biotechnology BioAnalytical Services Laboratory. All sequencing was performed on an ABI 3130 XL Genetic Analyzer (Applied Biosystems) using the dye terminator method. Sequences were aligned to our own databases and those of GenBank using the freeware BioEdit (Hall 1999). Chromatograms from all sequences were visually inspected for quality before consensus-based assembly of forward and reverse complement strands (Huang 1992). Sequences were aligned using ClustalW (Thompson et al. 1994) and similarity was calculated for pairwise comparisons (Hall 1999).

Mycobacterial species and strains used in the present study were obtained from the American Type Culture Collection (ATCC). All other sequences used in the analyses were obtained directly from GenBank, or entered manually from referenced literature. DNA was extracted from isolates for sequencing from known cultures in all cases by boiling cell suspensions in TrisEDTA (TE) buffer (Afghani \& Stutman 1996). Мусоbacterium marinum isolated from captive Atlantic menhaden (VAMDRCVM FL03-23) was used as the inoculum to generate control tissue blocks.

\section{RESULTS}

From 1975 to 1985,37 cases were available for histological examination. Of these, 5 contained granulomas that were non-parasitic. Ziehl-Neelsen staining revealed acid-fast, non-branching bacteria in a total of 2 sections during 1984 to 1985 (Fig. 1). Genus-specific PCR was successful for these 2 cases.

\section{5 to 1980}

Of the 21 cases available from 1975 to 1980, only 3 fish had apparent non-verminous granulomas (Table 1). New sections of these tissues stained with Ziehl-Neelsen revealed no AFB. PCR amplification of the ITS was not successful for these tissues. No other 


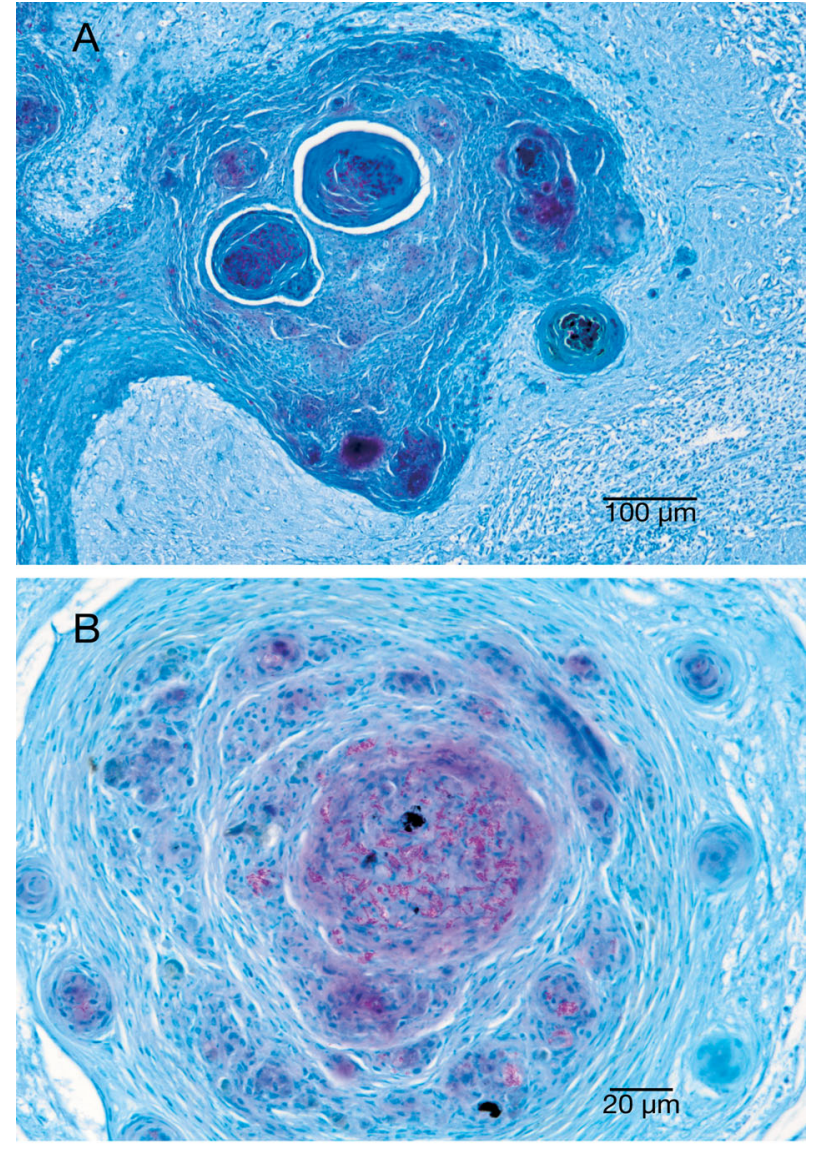

Fig. 1. Morone saxatilis. Photomicrographs of granulomatous inflammation from archival striped bass tissues. All tissues stained with Ziehl-Neelsen. (A) Spleen of fish 84-42, (B) acidfast bacteria in granuloma core of fish 85-4

information was available for these cases other than location and date of collection.

\section{0 to 1985}

From 1980 to 1985, 16 cases were available for analysis. Little information other than the location of collection was available for these cases. During 1984 to 1985, 2 adult striped bass were found with severe mycobacteriosis (Fig. 1). Fish 84-42 was captured in the Tred Avon River, a tributary of the Choptank River, MD, USA, in October of 1984. It was an adult fish based on tissue size, but no other information was available. Granulomatous inflammation was apparent in liver, spleen, posterior kidney, and heart, with AFB present in all tissues. The extent of tissue damage varied with organ. Poorly developed, large, and often coalescing granulomas accompanied almost complete fibrosis of the spleen. Eosinophillic granular cells and
Table 1. Morone saxatilis. Wild-collected, Chesapeake Bay striped bass available from 1975-1985 presented in 5 yr intervals. NVG: non-verminous granuloma; $\mathrm{AFB}+$ : positive identification of non-branching, acid-fast bacteria; PCR+ reflects successful amplification of the intergenic transcribed spacer

\begin{tabular}{|lcccc|}
\hline Year & Cases & NVG & AFB+ & PCR+ \\
\hline $1975-1980$ & 21 & 3 & 0 & 0 \\
$1981-1985$ & 16 & 2 & 2 & 2 \\
\hline
\end{tabular}

lymphocytic infiltrate were common within the fibrous meshwork. High concentrations of bacteria were present within many granuloma cores; however, individual bacteria were also readily discernable within macrophages outside of granulomatous lesions. Liver sections contained multiple granulomas in various stages of development, largely surrounded by normal hepatic tissue. Mature granulomas were most often condensed, with cores containing ceroid pigments and necrotic debris surrounded by a thin fibrous capsule. Pericarditis was evident on ventricle tissues of the heart, with granulomas present both within this inflammatory layer and the ventricle and atrium. While granulomas were less numerous, AFB were visible within cores. Anterior kidney sections contained numerous granulomas in various stages of development accompanied by extensive renal tubular necrosis. This specimen was deposited by Dr. Martin Newman in the Registry of Marine Pathology (ROMP \#404) currently maintained by the Registry of Tumors in Lower Animals, Washington, DC.

Fish 85-4 was collected in January of 1985 from the Choptank River, MD, based on tissue submission. This fish was an adult specimen, based on tissue size, but no other information was available. Splenic granulomas varied considerably in size and organization, ranging from small (10 to $12 \mu \mathrm{m}$ diameter) and well-organized to large ( 200 $\mu$ m diameter) and poorly contained, as described previously. However, fibrosis of the organ was not apparent, and most tissue was normal, suggesting reduced severity of infection. AFB were readily visible in both types of granulomas; however, bacteria in the latter was found throughout the confines of the granuloma and not restricted to pockets within the core. Anterior kidney, muscle tissue, and intestine were also examined and appeared normal.

Sequence analysis of the ITS region from bacterial DNA isolated from spleens of both specimens showed high similarity with the fish pathogenic mycobacteria clade reported in Chesapeake Bay striped bass. Only one substitution was noted for Mycobacterium ulcerans and for $M$. shottsii at differing loci among this group. PCR amplification of IS2404 and IS2606 were weakly positive for both archived tissues and strongly 
positive for M. pseudoshottsii and M. ulcerans based on band intensity. M. marinum and M. shottsii did not produce bands. Sequence analysis of a $500 \mathrm{bp}$ region of the IS2404 showed high similarity between both isolates $(99.5 \%)$ and with M. pseudoshottsii (99\%) and less with published sequences for M. ulcerans (AF003002) (97\%) and M. marinum (EF164897) (87.0\%). Sequences of a $330 \mathrm{bp}$ segment of IS2606 were identical $(100 \%)$ to M. pseudoshottsii and our isolates, with all differing from $M$. ulcerans by only one substitution (99\% similarity). Sequences obtained from the central region of the erp gene showed 100\% similarity of DNA from specimens 84-42 and 85-4 and M. pseudoshottsii, with $M$. ulcerans, M. marinum, and $M$. shottsii having a minimum of 30 additional nucleotides in this region.

\section{DISCUSSION}

Mycobacteriosis, as diagnosed by AFB within granulomas, was apparent in archived tissue of wildcollected striped bass at least 12 yr before initial reports in Chesapeake Bay striped bass (Heckert et al. 2001, Rhodes et al. 2001). Given other reports of this disease during the same time period, the presumed ubiquitous distribution of mycobacterium in the environment, and the known susceptibility of striped bass (Wolf \& Smith 1999), these findings should not be surprising. In the early 1980s Sakanari et al. (1983) described a high prevalence of tubercular lesions in Pacific coast striped bass. Mycobacterium was suggested to be the causative agent based on histopathology, although the species was not determined. MacKenzie (1988) reported presumptive mycobacteriosis (not culture confirmed) in Northeast Atlantic mackerel from 1979 to 1986 based on observations of grayish-white nodules in the spleen. Thus, reports of presumptive mycobacteriosis in wild fish of the same species and other fish species in the Atlantic Ocean coincide with our initial findings in Chesapeake Bay.

While the occurrence of granulomatous inflammation was low $(5 \%)$ in our retrospective analysis, we cannot speak of prevalence of disease during any time period reported. Fish examined during this review were collected in an opportunistic manner from concerned anglers or watermen, or from small-scale investigations of reports of unhealthy fish. Thus, sampling may be biased, and comparisons should not be made to samples outside of this collection.

One hypothesis concerning the current epizootic of mycobacteriosis infers that striped bass introduced to the Chesapeake Bay during the intensive stocking efforts of the mid 1980s to early 1990s may represent a source of mycobacterial pathogens. Our initial finding from 1984 pre-dates the extensive stocking efforts coordinated by the Atlantic States Marine Fisheries Commission (Upton 1993). From 1985 to 1992 over 6.5 million Phase II and III juveniles were released into Chesapeake Bay (Rulifson \& Laney 1999). However, striped bass strains have been stocked on a smaller scale around the country since the late 1800 s. In particular, both Roanoke River, NC-strain and Chesapeakestrain striped bass were stocked in Virginia Rivers as early as 1975 (Rulifson \& Laney 1999), and similar small-scale stockings occurred in Maryland as early as 1960 (S. Early, Maryland Department of Natural Resources, pers. comm.). In addition, nearly 1.2 million larval striped bass were released in 1981 by the State of Maryland (Tarnowski 1999). Thus, the timeline established with our study yields little insight to the potential role of stocking, and it is unlikely that these linkages can be made with the paucity of data available.

Retrospective analysis of tissues using current molecular techniques offers an important epidemiological tool. The sensitivity and specificity of PCR, in particular, allows for rapid identification of pathogens not possible in earlier investigations. For the positive samples, we amplified mycobacterial DNA and applied multiple gene sequencing to attempt identification to species level. The ITS region of the 16-23S rRNA gene has successfully been used for the differentiation of fish mycobacterial isolates (Levi et al. 2003, Kent et al. 2004), but is also conserved enough for the development of genus level assays (Bruijnesteijn van Coppenraet et al. 2004). Within the fish pathogens of the Mycobacterium tuberculosis clade, the ITS fragment does not have sufficient variability to separate $M$. marinum, M. shottsii, M. pseudoshottsii and M. ulcerans. These closely related bacteria are difficult to separate owing to their high similarity for many gene targets, especially the most common 16S rRNA gene (Rhodes et al. 2005).

The erp gene codes for an extracellular protein are thought to be genus-specific to mycobacteria (Mendonca-Lima et al. 2001). Recent work suggests that it is a virulence determinant in both Mycobacterium marinum and $M$. tuberculosis allowing for bacterial replication within host macrophages (Cosma et al. 2006). An adjoining fragment of the central region of the erp gene was shown by Rhodes et al. (2005) to be capable of distinguishing M. marinum, $M$. shottsii, and $M$. pseudoshottsii. Amplification of this region using our primer set was easily accomplished from case 84-42. However, a nested approach was necessary to obtain product from $85-4$, most likely relating low copy number of the target gene in this sample.

The insertional sequences (IS) IS2404 and IS2606 were previously thought to be specific for Mycobac- 
terium ulcerans (Stinear et al. 1999). However, recent evidence suggests that they may be associated with other members of the $M$. tuberculosis clade (Rhodes et al. 2005, Ranger et al. 2006). Insertional sequences are mobile genetic elements available in high copy numbers within $M$. ulcerans and are of interest for their potential to serve as a marker for mycolactone producing mycobacteria (Ranger et al. 2006). While we were unable to amplify IS2404 or IS2606 from M. shottsii or M. marinum, strain variability in the detection of these elements has been reported and success may be somewhat dependent on the use of high-fidelity polymerase (Rhodes et al. 2005, Ranger et al. 2006).

Archived tissues are an invaluable source for examining the epidemiology of disease and establishing timelines relevant to other factors influencing a population. This study demonstrates that mycobacterial infections in Chesapeake Bay striped bass are not a recent phenomenon. Members of the same group of pathogens involved in the current epizootic were present in striped bass since at least 1984. The DNA isolates obtained in this retrospective study most closely resemble Mycobacterium pseudoshottsii. While this study used fish from Chesapeake Bay, we currently are also examining archived tissues from other geographical regions to gain an understanding of the historic distribution of Mycobacterium spp. in finfish.

Acknowledgements. We are grateful for the efforts of S. Fasiludeen (UMD-COMB), who conducted sequencing for this project. A special thanks to A. Baya (UMD-VAMDCRM) and C. Ottinger (USGS NFHL) for providing isolates used in the study, to M. Matsche (MDNR) for photomicrography assistance (Fig. 1), and to C. Stine (UMD), A. Leight (NOAA), and S. McLaughlin (NOS) for critical review. This work was supported by the NOAA/NOS Cooperative Oxford Laboratory. The research in this article does not signify that the contents necessarily reflect the views and policies of the agencies involved, nor do trade names or commercial products constitute endorsement or recommendation for use.

\section{LITERATURE CITED}

Afghani B, Stutman HR (1996) Polymerase chain reaction for diagnosis of $M$. tuberculosis: comparison of simple boiling and a conventional method for DNA extraction. Biochem Mol Med 57:14-18

Bruijnesteijn van Coppenraet ES, Lindeboom JA, Prins JM, Peeters MF, Claas ECJ, Kuijper EJ (2004) Real-time PCR assay using fine-needle aspirates and tissue biopsy specimens for rapid diagnosis of mycobacterial lymphadenitis in children. J Clin Microbiol 42:2644-2650

> Colorni A, Avtalion R, Knibb W, Berger E, Colorni B, Timan B (1998) Histopathology of sea bass (Dicentrarchus labrax) experimentally infected with Mycobacterium marinum and treated with streptomycin and garlic (Allium sativum) extract. Aquaculture 160:1-17

Cosma CL, Klein K, Kim R, Beery D, Ramakrishnan L (2006) Mycobacterium marinum ERP is a virulence determinant required for cell wall integrity and intracellular survival. Infect Immun 74:3125-3133

Crumlish M, Diab AM, George S, Ferguson HW (2007) Detection of the bacterium Flavobacterium psychrophilum from a natural infection in rainbow trout, Oncorhynchus mykiss (Walbaum), using formalin-fixed, wax-embedded fish tissues. J Fish Dis 30:37-41

Hall TA (1999) BioEdit: a user-friendly biological sequence alignment editor and analysis program for Windows 95/98/NT. Nucleic Acids Symp Ser 41:95-98

> Heckert RA, Elankumaran S, Milani A, Baya A (2001) Detection of a new Mycobacterium species in wild striped bass in the Chesapeake Bay. J Clin Microbiol 39:710-715

> Huang X (1992) A contig assembly program based on sensitive detection of fragment overlaps. Genomics 14:18-25

Jacobs JM, Stine CS, Baya AM, Kent ML (2009) A review of mycobacteriosis in marine fish. J Fish Dis 32:119-130

Kaattari IM, Rhodes MW, Kator H, Kaattari SL (2005) Comparative analysis of mycobacterial infections in wild striped bass Morone saxatilis from Chesapeake Bay. Dis Aquat Org 67:125-132

- Kaattari IM, Rhodes MW, Kaattari SL, Shotts EB (2006) The evolving story of Mycobacterium tuberculosis clade members detected in fish. J Fish Dis 29:509-520

Kent ML, Whipps CM, Matthews JL, Florio D and others (2004) Mycobacteriosis in zebrafish (Danio rerio) research facilities. Comp Biochem Phys C 138:383-390

Levi MH, Bartell J, Gandolfo L, Smole SC and others (2003) Characterization of Mycobacterium montefiorense sp. nov., a novel pathogenic Mycobacterium from moray eels that is related to Mycobacterium triplex. J Clin Microbiol 41:2147-2152

MacKenzie K (1988) Presumptive mycobacteriosis in Northeast Atlantic mackerel, Scomber scombrus L. J Fish Biol 32:263-275

> Mendonca-Lima L, Picardeau M, Raynaud C, Rauzier J and others (2001) Erp, an extracellular protein family specific to mycobacteria. Microbiology 147:2315-2320

Ottinger CA, Jacobs JM (2006) USGS/NOAA Workshop on Mycobacteriosis in Striped Bass. NOAA Tech Memo NOS NCCOS 41

Overton AS, Margraf FJ, Weedon CA, Pieper LH, May EB (2003) The prevalence of mycobacterial infections in striped bass in Chesapeake Bay. Fish Manag Ecol 10: 301-308

- Ranger BS, Mahrous EA, Mosi L, Adusumilli S and others (2006) Globally distributed mycobacterial fish pathogens produce a novel plasmid-encoded toxic macrolide, Mycolactone F. Infect Immun 74:6037-6045

> Rhodes MW, Kator H, Kotob S, Van Berkum P and others (2001) A unique Mycobacterium species isolated from an epizootic of striped bass (Morone saxatilis). Emerg Infect Dis 7:896-899

Rhodes MW, Kator H, Kotob S, van Berkum P and others (2003) Mycobacterium shottsii sp. nov., a slowly growing species isolated from Chesapeake Bay striped bass (Morone saxatilis). Int J Syst Evol Microbiol 53:421-424

Rhodes MW, Kator H, Kaattari I, Gauthier D, Vogelbein W, Ottinger CA (2004) Isolation and characterization of mycobacteria from striped bass Morone saxatilis from the Chesapeake Bay. Dis Aquat Org 61:41-51

Rhodes MW, Kator H, McNabb A, Deshayes C and others (2005) Mycobacterium pseudoshottsii sp. nov., a slowly growing chromogenic species isolated from Chesapeake Bay striped bass (Morone saxatilis). Int J Syst Evol Microbiol 55:1139-1147

Rulifson RA, Laney RW (1999) Striped bass stocking programs 
in the United States: ecological and resources management Issues. DAO Canadian Stock Assessment Secretariat Resource Document 99-07, Ottawa

Sakanari JA, Reilly CA, Moser M (1983) Tubercular lesions in Pacific Coast populations of striped bass. Trans Am Fish Soc 112:565-566

Stinear T, Ross BC, Davies JK, Marino L and others (1999) Identification and characterization of IS2404 and IS2606: two distinct repeated sequences for detection of Mycobacterium ulcerans by PCR. J Clin Microbiol 37:1018-1023

Stoskopf MK (1993) Bacterial diseases of freshwater tropical fishes. In: Stoskopf MK, Saunders WB (eds) Fish medicine. WB Saunders, Toronto, p 269-277

Tarnowski M (1999) A historical background for striped bass landings in Maryland. Maryland Department of

Editorial responsibility: David Bruno,

Aberdeen, UK
Natural Resources Fisheries Service, MD. http://mddnr. chesapeakebay.net/mdcomfish/stripedbass/sbfactrev.htm Thompson JD, Higgins DG, Gibson TJ (1994) CLUSTAL W: improving the sensitivity of progressive multiple sequence alignment through sequence weighting, position-specific gap penalties and weight matrix choice. Nucleic Acids Res 22:4673-4680

Upton HF (1993) Atlantic States Marine Fisheries Commission striped bass stocking summary. Striped Bass Stocking Technical Advisory Committee, ASMFC, Washington, $\mathrm{DC}$

Wolf JC, Smith SA (1999) Comparative severity of experimentally induced mycobacteriosis in striped bass Morone saxatilis and hybrid tilapia Oreochromis spp. Dis Aquat Org 38:191-200

Submitted: March 3, 2008; Accepted: April 28, 2009

Proofs received from author(s): June 11, 2009 